\title{
DIVAN ŞiiRINDE RESIM VE HEYKEL
}

\section{Painting and Sculpture in Divan Poetry}

\section{Sedat KARDAŞ*}

\begin{abstract}
öz
Sanat, yaratıclığın ya da hayal gücünün dışavurumudur. Sanat kendi içerisinde dallara ayrılır. Bu sanat dalları birbirleriyle sürekli bir ilişki içerisindedir. Bir sanat dalı, diğer bir sanat dalını göz ardı edemez. Dolayısıyla bir sanat dalını diğer bir sanat dalından kesin hatlarla ayırmak oldukça zordur. Edebiyat sanatı da şüphesiz diğer sanat dallarından yararlanır. Bunların başında güzel sanatlar içerisine dâhil ettiğimiz sanatlar gelir. Edebiyatın malzemesi kelimelerdir. Dolayısıyla bu sanatları kullanırken dilin olanaklarından yararlanır. Divan şiirinde diğer sanat dallarının kullanımına çok sık rastlıyoruz. Bunların başında musikî, resim, heykel gibi sanatlar gelir. Divan şiiri bu sanatları kullanırken, sözcüklerin gücünden yararlanmış ve adeta bu sanatları kelimelerle çizmiştir. Bu çalışmada genel hatlarıyla Divan şiirinde, resim ve heykel sanatlarının kullanımı üzerinde durulmuştur.

Anahtar sözcükler: Sanat, Resim, Heykel, Şiir, Divan Şiiri.

\section{ABSTRACT}

Art is the expression of creativity or imagination. Art is divided into branches. These branches of Art are in a constant relationship. One branch of art can not ignore the other branches of art. Therefore, it is quite difficult to seperate one branch of art sharply from another. Undoubtedly, literature too benefits from other forms of art. Arts that we have included in the fine artsa re the primary. Material of literature is words. Therefore, lt benefits from facilities of language when utilizes these arts. In Divan Poetry we encounter with the use of other branches of art very often. Among these are arts such as music, painting, sculpture. While making use of these arts, Divan Poetry has benefited from the power of words, and almost portrayed these arts. In this study, the use of painting and sculpture in the Divan Poetry emphasized in general terms.

Key words: Art, Painting, Sculpture, Poetry, Divan Poetry.
\end{abstract}

\section{Giriş}

Sanat, toplum adını verdiğimiz organizasyon içinde ortaya çıkmış, o toplumun gelişmesiyle birlikte yaşamıştır. Hatta bir toplumun varlığında din, dil, töre ne kadar önemliyse, sanat da o kadar önemlidir. Sanatsal gelişim, toplumsal gelişmeye ve toplumsal yaşamın yapısına bağlıdır. Sanat ve toplum, etkileşim içindedir. Toplumsal yaşam sanatı, sanat da toplumu etkilemektedir. Dolayısıyla

\footnotetext{
* Atatürk Üniversitesi, Edebiyat Fakültesi, Türk Dili ve Edebiyatı Bölümü, (sedat_kardas@hotmail. com)
} 
sanat toplumdan beslenir. Bir toplumun gelişmişlik seviyesi o toplumdaki sanatın gelişme düzeyi ile paraleldir.

Sanat da bilim gibi düzenin gerekli ve temel unsurlarından biridir; bu yüzden herhangi bir uygarlığın ya da çağın tarihini, sanatının tarihini dahil etmeden bir bütün olarak yazmak mümkün değildir (Hollingsworth 2009: 15).

Edebiyat ve güzel sanatlara gelince, bunlar birbirleriyle sürekli bir ilişki içerisinde olmuştur. "Edebiyat, insanın dildeki güzellik cevherini keşfettiği günden beri güzel sanatların ana dallarından biri olmuş. Söz güzelliğinin, mimari, heykel, resim ve musikiye göre bazı üstünlüklere sahip olması, edebiyatın en yaygın ve en gelişmiş sanat dalı olmasına zemin hazırlamış" (Çetişli 2008: 264). Güzel sanatların genelinde plastik malzeme kullanılırken edebiyat ve müzik ise sese ve söze dayalı bir sanattır. Edebiyatın malzemesi kelimelerdir ve edebiyat dille gerçekleştirilen bir güzel sanatlar etkinliğidir. Edebiyatın asıl amacı güzel sanatların en önemli öğesi olan estetik zevk duygusunu dil aracılığıyla gerçekleştirmektir.

Divan şiiri de görsel sanatlara bu açıdan yaklaşır. Divan şiiri kelimelerin gücünden ve belirli mazmunlardan yararlanarak, anlatmak istediği şeyi tasvir eder ve okuyucusunun gözünde adeta bir tablo oluşturur. Bu durumun oluşmasında şüphesiz, İslam'ın etkisi olmuştur. Günümüzde dahi sürmekte olan, ìslam'da tasvir yasağı var mı, yok mu tartışmalarının gölgesinde, Müslüman sanatçlar tasvirden ister istemez uzak durmuşlardır. Ancak Divan şiiri diğer din ve kültürlerden de yararlanmış bunun sonucunda kısmen de olsa resim ve heykele yer vermiştir. Bunu yaparken, görsel sanatlar ve onların terimlerinden yararlanmıştır. "Tasvir yasağı, Müslüman sanatçıları figürden kaçma ve figürü cansızlaştırma şeklinde ifade edebileceğimiz iki yola yöneltmiştir. Figürden kaçış, Müslüman sanatçıyı doğrudan doğruya soyut formlara yöneltir. Söz gelişi Arap alfabesindeki şekil repertuvarının başlangıçta plastik açıdan son derece elverişsiz olduğu halde, harf köşelerinin zamanla yuvarlaklaştırılarak (Ma'kılî yazıdan Kufìye, oradan diğer yazı karakterlerine geçiş) zengin imkanlara sahip bir ifade vasıtasının elde edilmesi, bu eğilimin önemli sonuçlarından biridir. Figürü cansızlaştırma eğilimi ise, bir yandan tabiattan alınan şekilleri stilize ede ede asıl kaynağından büsbütün uzaklaştırarak soyut formlara dönüştürülmesini sağlamış, bir yandan da diğer geleneklerden devralınan resmi bazı unsurlarından arındırarak bir çeşit nakış haline getirmenin prensibi olmuştur"(Ayvazoğlu 1993: 190).

Divan şiirinin yararlandığı görsel sanatların başında resim ve heykel gelir. Bunların yanında, süsleme sanatları olan; ebru, tezhip, hat ve minyatür'den de yararlanır. Bunlardan minyatür sanatına değinmekte yarar vardır. 
Minyatür, genellikle el yazması kitaplarda yer alan küçük boyutlu renkli resim. Kelime ortaçağ Avrupa'sında hazırlanan el yazmalarının bölüm başlarında metnin ilk harfinin etrafında kızıl-turuncu minium ile (sülüğen, sülyen, kırmızı kurşun tozu) yapılan miniatura adlı tezhipten gelmekte ve "sülüğenle boyanmış" anlamını taşımaktadır; ancak zamanla minor (küçük) kelimesinin etkisinde kalarak "küçük (resim)" anlamını da kazanmıştır. İslam sanatında minyatüre "tasvir", minyatür sanatçısına "musavvir" veya "nakkaş" adı verilmiştir. Metni açıklamak amacıyla kitap sayfalarına veya bir albüm içinde toplanmak için tek yaprak halinde suluboya ve altın, gümüş yaldızla yapılan minyatürler, ışık-gölge oyunlarıyla derinlik duygusu kazandırılmayan küçük boyutlu resimlerdir (Mahir 2005: 118). Minyatür sanatı tasvir yasağı varsayımına rağmen bütün Türk devletlerinde kendine yer bulmuştur. Osmanlılar devrinde de Nakkaş Osman ve Levnî gibi isimler bu alanda çok önemli eserler vermişlerdir.

Türk minyatür sanatının en önemli örneklerinden birçoğu Çağatay sahasına aittir. Özellikle birer sanat merkezi konumunda olan Herat ve Şiraz şehirlerinde resim ve heykel alanında önemli eserler ortaya konmuştur. "Hüseyin Baykara devrinde Herat önemli bir sanat merkezi haline gelmiştir. Edebiyatta Farsça yerine Çağatay Türkçesi'nin kullanıldığı bu devirde Hüseyin Baykara veziri Ali Şîr Nevâi ile birlikte şairleri, hattatları ve minyatür ustalarını desteklemiştir. Resmini imzalayan az sayıdaki sanatçıdan biri olan Bihzâd bu dönemde yetişmiş ve minyatürlerinde insan vücudunun çeşitli faaliyet anlarında ortaya koyduğu hareketleri gerçekçi bir resim diliyle yansıtmıştır"(Mahir 2005: 120). Aşağıdaki beyitte Çağatay sahasındaki resim ve heykel alanındaki gelişmelere atıfta bulunmuştur:

Büt-perest-i cemâl-i san'atıdır

Büt tırâşân-ı Halluh u Nevşâd (Şeyh Galip, K. 24/11:90)

(Nevşâd ve Halluh heykeltıraşları, sanatın yüz güzelliğine tapanlardır.) Beyitte Nevşad ve Halluh ile heykeltıraşlık arasında bir ilgi kurulmuştur. "Nevşad: Türkistan'da bir şehirdir. Ehli hüsn ve cemal ile maruftur."(Mütercim Asım Efendi: 2009). Halluh ise Orta Asya'da yaşamış olan Türk boyu Karluklara Fars kaynaklarında verilen isimdir. Bunun yanında Orta Asya'da bir şehir olarak da kullanılmıştır.

Divan şiirinde resim ve heykelden bahsedilirken, bu konuların genel olarak şu bakış açları etrafında işlendiği tespit edildi.

1. Görsel sanatların doğrudan kullanımı

11. Dini terminoloji ile birlikte kullanma 
III. Eski Edebiyatta adı geçen ressam, heykeltıraş ve tarihi kişilikler ile ilişkilendirme

IV. Çeşitli inanış ve uygulamalara atıfta bulunma

V. Şairin şiirini ve kendini övme vasıtası olarak görsel sanatları kullanması

\section{Görsel Sanatların Doğrudan Kullanımı}

Görsel sanatlara, daha çok herhangi bir şeyin tasviri yapılmak istendiğinde başvurulur. Divan şiirinde şairler, tasviri en güzel şekilde yapabilmek için resim, minyatür, nakış, ebru gibi sanatların terminolojisinden sonuna kadar yararlanmıştır. Bu terminoloji sayesinde şairler bazen bir tabloyu ustalıkla çizebilmekte, bazen de şiirlerine usta bir nakkaşın elinden çıkmış hissi verebilmektedir.

Resm etmişim gözümde hayâlini gûyiyâ

Nakş-1 nigârı sâgar-1 mercâna yazmışım (Ahmet Paşa, G. 199/4:188)

(Hayalini gözümde resm etmiş gibi, mercan kadehe nakış ve resim yazmışım.) Şair bu beyitte bir tablo çizmiştir. Sevgiliyi hayal ederek göz önüne getirmiş ve bu hayalin ne kadar canlı olduğunu anlatabilmek için mercan kadeh üzerindeki nakış ve resimlere benzetmiştir. Eskiden boyalı resimlere nakış denirdi. Nakış yapan ustalara Nakkaş, atölyelerine de nakışhane denilirdi. Minyatürler de nakış sayılırdı. Nigâr ise resim, resim gibi güzel olan sevgili anlamına gelmektedir. Bu nedenle Divan şiirinde mecaz-ı mürsel yoluyla sevgili yerine kullanılır ve nakış kelimesi ile tenasüp yapılır.

Bâ-hayâl-i zülf-i o der-dîde mî ârem sirişk

Resm bâşed endek âbî der-mürekkeb rîhten (Kardaş 2012:238)

(Onun saçlarının hayali ile göze gözyaşı getirdim; mürekkebe biraz su dökünce resim oldu.) Bu beyitte de süsleme sanatlarından olan Ebru sanatı́na atıfta bulunulmuştur. "Ebru sanatının adı Farsça Ab-ru (su yüzü) veya Çağatayca ebre'den (hare gibi dalgalı ve damarlı kumaş, kağıt) gelmektedir. (Sözen 1998) Ebru bir çeşit resimdir. Su sathındaki boyaların kağıda çıkarılmasıyla oluşur (Pala 2004: 131). Ebru'nun menşei ebri (bulutlu) olması da mümkündür. Bu beyitte de şair sevgilinin saçlarının hayali ile ağlamış, gözüne yaşlar dolunca bu hayalin resme dönüştüğünü vurgulamıştır.

Zamân-ı rezm geçdi şimdi vakt-i bezmdir söylen

Çemen nakş eylesin nakkâşlar püşt-i kemân üzre (Nedim, K. 6/2:27)

(Savaşma zamanı geçti, şimdi meclis zamanıdır; söyleyin nakkaşlar yayın üstüne çemeni nakş eylesinler.) Şair bu beyitte savaş zamanının geçti, artık yiyip 
içme, eğlence meclisleri kurma vakti olduğunu söyleyerek, nakkaşların yayları nakışlarla süslemelerini istemektedir. Bilindiği üzere eskiden savaş aletleri çeşitli şekil ve desenlerle süslenmiştir. Ok ve yay da bu aletlerdendir.

Halk-ı cihânı nakşına eyler firîfte

Nakkâş-1 rûzgâr 'aceb rengler geçer (Baki, G. 134/5:185)

(Zamanın nakkaşı tuhaf suretler geçer; cihanın halkı onun nakşına aldanır.) Beyitte geçen "Nakş" ve "reng" sözcükleri ile iham sanatı yapılmıştır. Nakş resim ve hile, reng de renk, suret, hile ve oyun anlamlarında kullanılmıştır.

Bûyı dil-keş semenün ferşi münakkaş çemenüñ

Mey-i bî-gış çekelüm hoş geçelüm leyl ü nehâr (Nev'î, K. 18/6:44)

(Yaseminin gönül çeken kokusu çemenin döşemesine nakşedilmiş; saf şarap çekelim, gece gündüzü hoş geçirelim.) Bu beyitte de gül bahçesinin tasviri yapılmışır. Yaseminin kokusu ile çemen o derece uyumlu olmuştur ki, bunu gören şair yaseminin kokusunun çemene nakşedildiğini düşünür. Buradan yasemin kokusunun çemeni süslediği anlamı da çıkarılabilir. Divan şiirinde baharın gelişiyle beraber insanlar gül bahçelerinde eğlence meclisleri kurarlar. Şair baharın geldiğini ifade ederek, zamanı güzel geçirme isteğindedir.

Divan şiiri görsel sanatlardan oldukça yararlanmıştır. Divan şiirinde sadece resim ve nakşı konu edinen gazeller de vardır. Bilindiği gibi divan şiirinde konu bütünlügü olan gazellere "yek-ahenk gazel" adı verilir. Nevi’ye ait aşağıdaki yek-ahenk gazel görsel sanatlara ait terminoloji üzerine kurulmuştur.

Safha-i gülzâra tasvir eyleyen gül nakşını

Haylî dil-keş baglamış gülşende bülbül nakşım

Buldı bülbül kendi göñlinde o nakş-ı dil-keşi

Yazdı yüz vech ile iller gonca-i gül nakşını

Yakmayınca âteş-i 'ışk-ı güle eczasını

Bu fena bagında bülbül bulmadı kül nakşını

Sûzen-i müjgânı geçdükçe dil-i pür-dâgdan

Şanuram işler harîr üzre karanfül nakşını

Câm-veş dil 'ş̧k ile pürdür anı işrâb ider

Kim yumak olmaz gönüülden Nev'iyâ mül nakşını. (Nev'î, G. 465:37ı) 


\section{Dini Terminoloji}

\section{A. Allah'ın Yaratıcı Vasfinı Anlatan Tasvir}

İslam düşüncesine göre dünyadaki her şey harici bir form (sûret) ve Batıni bir anlamdan (manâ) oluşur. Sûret görünüşü (zahir), manâ ise mistik özü (batın) temsil eder. Güzellik anlayışı da zahir (dış âlem) ve batın (iç âlem) arasındaki denge üzerine kuruludur. Mutasavvıflar iç âlemi (batını) keşfetme arzularından dolayı soyut (mücerret) olana yönelmişler, varlıkları mutlak güzelliği yansıtan ayna parçacıklarına benzetmişlerdir. Mutasavvıflar her varlıkta mutlak güzelin bir parçasını gördükleri için güzel ve güzeli temaşa edenin Allah olduğunu tekrarlamışlardır. (ìsen vd. 2006: 55). Kutsal ìslam sanatı, tüm halis kutsal sanatlar gibi, semavi gerçekliğin yeryüzündeki şecerelerinden birisidir. Bu sanat, bu bozulma ve ölüm dünyasına ait olmayan bir mükemmeliyeti kuşanmış ìslam vahyinin ruh ve biçiminin billurlaşmasıdır. İnsanoğlunun içinde yaşadı̆̆ı fani varlığın (ed-dünya) çerçevesinde, öte dünyanın (el-ahire) bir yansımasıdır (Yakup Çelik: 2003).

Divan şiiri, tecelli fikri etrafında oluşan bu dini terminolojiden çok sık olarak yararlanır. Divan şiirinde resim ve heykelin kullanımına baktığımızda, bu sanatların dini inanışlarla çok sık olarak yan yana geldiğini görürüz. Bu kullanımlara baktığımızda bunların başında Allah'ın yaratıcı vasfı etrafında gerçekleşen kullanımı gelir. Divan şiirinde nakkaş Allah'ın sıfatı yerine kullanılır. "Nakkaş-ı ezel ve nakkaş-ı sun' " gibi tamlamalar ile Allah'ın yaratıcı sıfatı (güzel bir şekilde yaratan) kastedilir. Buna paralel olarak gökyüzü, cennet, dünyanın görünümü de birer nakıştır. Yani Divan şiirinde Allah=Nakkaş ve Tabiat=Nakış diyebiliriz.

Musavvir-i ezel edeli nakşını tasvîr

Yüzünü hâke sürer Çîn içinde sûretler (Şeyhi, G. 60/3:156)

(Allah nakşını tasvir ettiğinden beri, Çin içinde resimler yüzünü toprağa sürer.) Beyitte Allah'ın yaratıcı sıfatı üzerinde durulmuştur. "Musavvir-i ezel" divan şiirinde Allah yerine kullanılır. Çin de resim ve çinicilikte çok ilerlemiştir. Şair sevgilinin güzelliğini ortaya koymak için, Allah seni yarattığından beri Çin içindeki resimler yüzünü toprağa sürer, diyerek sevgilinin o resimlerden daha güzel olduğunu vurgulamaya çalışmıştır.

Anı nakkâş-ı kudret-hâne-i feyz etmiş ol rütbe

Göreydi lâl olurdu noktasın Behzâd ile Mâni (E. Zihni, Na't 5/10:5)

(Onu o derece yaratmış olan nakkaşın noktasını Behzâd ile Mânî görseydi lal olurdu.) Behzad ve Mânî Divan şiiininde geçen ünlü ressamlardır. Bu kişiler 
hakkında ilerleyen sayfalarda geniş bilgiler verilecektir. Beyitte sevgilinin ne kadar güzel yaratıldığı üzerinde durulmuştur. Allah onu o kadar güzel yaratmıştır ki, şaire göre eğer Mânî ile Behzad onun bir noktasını görecek olsalar, hayretten dilleri tutulur konuşamazlar.

Şemse-i kasruñla şems-i çarhı nakkâş̧-1 ezel

Birisin resm-i zemîn itmiş birin resm-i zamân (Nev'î, K. 37/12:87)

(Allah, senin sarayının resimleri ile felekteki güneşin, birini yerin resmi, birini zamanın resmi yapmış.) Bu beyitte de Allah'ın yaratıcı sıfatına atıfta bulunulmuştur. Beyitte "şemse-i kasr ile resmi zemîn" ve "şems-i çarh ile resm-i zamân" arasında mürettep leff ü neşr vardır. Allah sarayın resimlerini yeryüzünün nişanı, felekteki güneşi de zamanın işareti olarak yaratmıştır.

Yazdı nakkâş-ı kazâ levh-i bahâristâne nakş

Bagladı nev-rûzda bülbül bir üstâdâne nakş (Bâkî, Gazel 2ı3/l:230)

(Kaza nakkaşı ilkbaharın levhasına nakş yazdı; Bülbül nevruzda üstada yakışırcasına bir nakış bağladı.) Bu beyitte ise Allah yerine "kaza nakkaşı" kullanılmıştır. Allah ilkbaharı nakşetmiş, bülbül de baharın habercisi olan Nevruzda ustaca bir beste bağlamıştır. ikinci mısradaki "nakş" kelimesi resim anlamında kullanılarak, müzik terimi olan beste anlamı kastedilmiştir. Böylece bu beyitte resim ve musikî sanatları bir arada verilmiştir.

\section{B. Dinlerin Bakış Açılarını Anlatanlar}

Divan şiirinde resim ve heykel gibi görsel sanatların kullanılmasında dini terminolojiden çok sık bir biçimde yararlanılır. Bu dini terminolojiden yararlanıldığını tespit ettiğimiz ikinci bir kullanım, dinlerin görsel sanatlara bakış açılarına göre şekillenen kullanımdır. Bu kullanımda bakış açısına atıfta bulunulan dinler olarak İslamiyet, Hıristiyanlık ve Maniheizm dinlerini tespit ettik.

1. İslam'ın Bakış Açısı: Günümüz İslam dünyasında yan yana getirmekte oldukça güçlük çekilen kavramlar arasında "islam" ile "sanat" da bulunmaktadır. Bugün İslam ülkelerinin hemen hemen hepsinde cemiyetin her kesiminden insanların bu iki kelimeyi bir arada düşünmekte bir hayli zorlandığını görmekteyiz. "Sanat"la "islam" kelimeleri bir arada kullanıldığında, kendisini dindar olarak kabul etmeyen kesim, İslam'1, sanata tahammül edemeyecek kadar "geri” görmekte; kendisini dindar olarak kabul eden, kesim ise sanatın i̇slam'la bağdaşmayacak kadar "kötü" ve "lüzumsuz" olduğunu düşünmektedir. Birbirinden o kadar uzak görüşleri savunan bütün bu insanların ortak noktaları tasvirin İslam'da yasak olduğu varsayımıdır (Çam 2008: 13). 
İslam'la sanatın bağdaştırılmasında güçlük çekilmesindeki problemlerden bir tanesi de "tasvir" veya "suret" isimleriyle bilinen resim ve heykelin bilhassa İslam öncesi devirlerde putperestlik amacıyla kullanılmış olmasıdır.

İslam sanatında tasvirin bulunmadığı, bu bakımdan İslam Sanatı içinde resim ve heykeltıraşlıktan söz edilmediği, İslamiyet'in ve özellikle dinin temel kitabı olan Kuranı Kerim'in tasviri yasaklamış olduğu artık çok eskimiş bir görüştür. Bu görüş, tamamen art niyetlere dayanarak veya hiçbir araştırma yapmadan yüzeyden bir değerlendirme ile bu konuya değinenlerin peşin düşüncesidir. Kur'anı Kerim'de bütün Oryantalistlerin de (Doğu ilmi ile uğraşanların) belirttiği gibi tasvirin yasak edildiğini gösteren bir ayet ve hüküm yoktur (Türker 2010: 30).

İslam'da resmin yasaklanması, açık konuşmak gerekirse sadece uluhiyeti temsil eden suretlerle ilgilidir; o halde bu yasak, on emirin bakış açısıyla veya daha açık bir ifadeyle, ìslam'ın yenilemeyi üstlendiği ibrahimî tevhid anlayışı ile ilgili bir yere oturur (Burckhardt 2005: 33). Buradan da anlaşıldığı üzere, çoğu düşünür tapmak için yapılmadığı sürece i̇slam'da tasvirin yasak olmadığını savunurlar.

Resim ve heykelin i̇slam'daki yeri konusunda oldukça farklı görüşler vardır. Ancak bu görüşler temelde, yasak olduğu ve yasak olmadığı şeklinde ikiye ayrılmaktadır. İslamda resim yapmanın yasaklandığını iddia edenler, genellikle bazı hadislerden yola çıkarlar. Ancak bu iddialar yorumlardan ibarettir ve varsayımdan öteye gitmemektedir. Yasağın olmadığını savunanlar ise önemli olan şeyin niyet olduğunu ve íslam dininde mutlak anlamda tasvirin yasak olmadığını, yasak olan şeyin putperestlik olduğunu ileri sürerler.

Bu bakış açılarına Divan şiirinde de rastlıyoruz. Ancak belirtmek gerekir $\mathrm{ki}$, divan şiirinde resim ve nakış güzellik için, heykel ise daha çok put yerine ve kâfirlik ile puta tapmayı çağrıştıracak şekilde kullanılmıştır. Şüphesiz bunda Osmanlı döneminde, sivil yapılardaki çiniler hariç tasvire önem verilmemiş olması önemli rol oynamıştır.

Sûret ü nakşı gözleyen kâfîr ü büt-perest olur

Âşık-ı sâdık olanın hâtırı lem-yezeldedir (Şeyhi, G. 37/4:133)

(Resim ve nakşı gözleyen kâfir ve putperest olur, sadık aşık olanın gönlü kalıcıdır.) Birinci mısrada, resim ve nakşı gözleyen kâfir ve putperest olur denmiştir. ilk bakışta bu mısra İslam'da tasvir yasağını savunanların düşünceleriyle paralellik varmış gibi görünür. Ancak beyti bütün olarak düşündügümüzde aslında şairin görüntüye, sadece görünene takılıp kalan ve görünenin ötesine geçemeyen tek boyutlu yasayan insanları eleştirdiğini görürüz. 
Levh-i Mahfûza ne lâzım dûde ile resm-ü-nakş

Anda hôd esrârı kevnün âşikârâdur yine (Necati Bey, K. 23/27:109)

(Levh-i Mahfûz'a çıranın dumanıyla resim ve nakış yapmaya ne gerek var; onda olan kendi sırları aynı zamanda bellidir, açıktır.) Beyitte geçen "levh-i mahfuz", Allah tarafindan takdir edilen şeylerin yazılı olduğu manevi levha anlamındadır. Bu levhada olup biten açıkır ortadadır, o yüzden çıranın dumanıyla resim ve nakış yapmaya gerek yoktur. Bilindiği gibi İranlılar Kuran-ı Kerim ve diğer dini kitapları resimlerle süslemişlerdir. Ancak Osmanlılar, insanın dikkatini başka şeylere çekebileceği endişesiyle böyle bir uygulamaya gitmemiştir. Bu beyit bu düşünceyle paralellik gösterir.

Hey 'aceb ol büt-i kâfirde bu lutf-ı Yezdân

Hatt-ı Cibrîl-i Emîn çeşm-i füsûn- sâz Mesîh (Şeyh Galip, G. 33/2:266)

(Yezdan'ın (Allah) lütfu olan güvenilir Cebrail'in hattı ve Hz. İsâ'nın büyüleyici gözü'nün o kâfir putunda olması ne tuhaftır.) Vahiy getiren melek olan Cebrail kendi nefesini Meryem'e üfleyerek İsa'yı canlı yapmıştır. İsa Cebrail'in Meryem'e üflediği ruhtur. Bu yüzden Divan şiirinde Cebrail ile Hz.İsa çok sık olarak birlikte anılır. Ayrıca Cebrail kanatlarıyla sevgilinin güzelliğine bir gölgelik olarak da kullanılır. Hz. İsa da gösterdiği çeşitli mucizeler nedeniyle büyücü olarak nitelendirilir. Şair beyitte bu özelliklerin bir kâfir putunda olmasına şaşırmaktadır.

2. Hıristiyanlığın Bakış Açısı: Hıristiyanlık, İsa, Meryem ve havarilerin, meleklerin resim ve heykellerini kiliselerde, ibadet yerlerinde doğal hale getirmiştir. 8. yüzyılda Hıristiyanlık içinde heykelleri kırma ve iconoclasm tepkisi meydana gelmiştir.

İslam'ın Resme karşı olan tutumunu Yunan Ortodoks Kilisesi'ninkiyle karşılaştırmak yararlı olacaktır. Bizans Kilisesi'nin, muhtemelen ìslam örneğinden etkilenmeksizin, bir ikonoklast krizi yaşadığı bilinmektedir. Şüphesiz, kilise kutsal imajın, yani ikonun rolünün tanımlanması üzerinde bir daha düşünmek durumunda kalmışı ı ve Yedinci Ekümenik Konsül, imaj (resim) hayranlarının zaferini onaylayarak, gerekçeli kararını aşağıdaki sözlerle ilan etti: "Tanrı, Bizathî, mümkün olan tüm tasvir ve temsilin ötesindedir; ama ilahî kelam beşeri bir mahiyete büründüğüne göre, ki o, onu ilahi güzellikle doldurarak tekrar kendi asli suretiyle birleşmiştir; Tanríya İsa'nın beşeri görüntüsü (image) vasıtasıyla ibadet edilebilir ve edilmelidir." Bu ilahi tecessüm doğmasının uygulanmasından başka bir şey değildir ve bu durum meseleyi böyle görmenin islam'ın bakış açısından ne kadar uzak olduğunu gösterir (Burckhardt 2005: 33). 
Divan şiirinde İsa, Meryem, kilise, rahip, put, puthane mazmunları çerçevesinde bu konuya çok değinilmiştir. Bunlar genel olarak kâfirlik olarak değerlendirilmiştir.

Bikr-i Manîdir serâser sûret-i Meryemleri

Öyle bir büthânenin şimdi gönül nâkûsudur (Şeyh Galip, G. 52/6:278)

(Meryem'in resimleri baştan başa Mânînin eşsiz eserleridir, gönül şimdi öyle bir kilisenin çanıdır.) Beyitte Meryem'in resimleriyle süslenmiş bir kiliseden söz edilmektedir. Meryem, suret, nakus, büthane sözcükleriyle bir kilise tasviri yapılmıştır. Gönül bu kilisenin çanı olmuştur.

Ey sanem zünnâr-1 fitne küfr-i zülfündür k'anun

Her kılında asılan bin zâhidin imânıdır (Ahmet Paşa, K. 15/5:33)

(Ey put gibi güzel olan sevgili! Fitne kuşağı senin saçının karalığıdır; onun her kılında asılan bin zahidin imanıdır.) Birinci mısrada, "sanem-fitne-küfr-zülf" sözcükleri kötü imajları nedeniyle kâfirlik ve Hıristiyanlık ile bağdaştırılmışır. Divan şiirinde yine sevilmeyen tiplerden olan zahidin imanının da, bir putun saçlarında olduğu vurgulanmış ve yadırganmıştır.

Hevâ Mesîh-nefes bag şekl-i büthâne

Sarındı başına sünbül kebûd dülbendi (Nev'î, G. 519/3:394)

(Hava İsâ nefesli, bağ puthane şeklinde(dir); sünbül başına gök renkli (mavi) tülbent sarındı.) Beyitte bir bahar tasviri göze çarpmaktadır. Birince beyitte şair bağı puthaneye, havayı da İsa'nın nefesine benzetmiştir. Sümbülün açılmasını, tülbent sardı diyerek hüsn-i talil yapmıştır.

3. Maniheizmin Bakış Açısı: Her türlü iletişimde olduğu gibi, dini iletişimde de bir fikrin kendisi kadar, onun takdim biçimi de önemli olduğu için, tarih boyunca bütün dinler, devletler ve ideolojiler, sanat eserinin bu gücünden faydalanmak istemiş̧lerdir. Mani dini mensupları, kutsal kitaplarının daha iyi okunması için onları resimlemişlerdir (Çam 2008: 24). Doğu dinleri, Budizm, Çin ve Hint dinlerinde sayısız kutsal resim ve heykel yapılmışır. Bunların başında Maniheizm dini gelmektedir.

Çin ülkesi, Mani dininin en çok yayıldığı yerdir. Mani'nin bir ressam olduğu ve kutsal kitabının da pek güzel minyatürlerle süslü olması dolayısıyla güzel yüz, daima Çin'e nispet edilmiştir. Edebiyatta Çin, adeta resim sanatının merkezi olarak işlenir (Pala 2004: 103). 
Saldı bir nat-ı münakkaş sahn-ı sahrâya sabâ

Kim onun nakşında hayrândır nigâristân-ı Çîn (Ahmet Paşa, K. 23/8:54)

(Saba rüzgârı çölün ortasına öyle süslü bir övgü saldı ki, Çindeki put sergisi onun nakşına hayran kaldı.) Nigaristan Divan şiirinde, hem put sergisi hem de Mani'nin eseri olarak geçer. En güzel resimlerin zikredilen eserde bulunduğu varsayılır. Şair saba rüzgârının çölde oluşturduğu nakış karşısında, bu resimlerin bile ona hayran kaldığını vurgulamıştır.

Göricek mu'cize-i nakşını sûretger-i Çîn

Götürüp hâme-sıfat barmagın îmân getürür (Baki, G. 131/2:183)

(Çin ressamı senin nakşının mucizesini görünce, kalem sıfatlı parmağını götürüp şehadet getirir.) Beyitte güzel yüz ile Çin resimleri arasında kıyaslama vardır. Ortada bir nakış vardır ve şair bunu mucize olarak nitelendirmektedir. Resimde üstat sayılan Çin ressamı eğer bu mucizevi nakşı görse kaleme benzeyen parmağını şaşkınlıktan ısıracaktır.

Çîn bütleri gibi yüzün ayına reşk eder

Nakş u nigârle âyîne-i âsumân dahı (Şeyhi, G. 172/4:268)

(Güneş bile nakış ve resimle, Çin putları gibi aya benzeyen yüzünü kıskanır.) Beyitte geçen "ayine-i asuman” güneş yerine kullanılmıştır. Sevgilinin yüzü aya benzetilmiştir. Yüzün güzelliği karşısında güneş de Çin putları gibi kıskançlık içerisine girmiştir.

Görse ol bârika-i hüsnü bütân-ı Keşmir

Tâb-ı hayretle erirlerdi büt-i mûm gibi (Nedim, G. 151/4:353)

(Keşmir putları o güzelliğin şimşeğini görse, hayretlerinin etkisiyle balmumundan heykel gibi erirlerdi.) Maniheizmin etki alanlarından birisi de Hindistan'dır. Bu etkinin sonucunda orada insanlar putlar yapmış ve onlara tapmışlardır. Keşmir burada mecaz-ı mürsel yoluyla Hindistan yerine kullanılmıştır. Sevgilinin güzelliği de şimşeğe benzetilmiş ve güzelliğin şimşeği gibi orijinal bir imge ortaya konulmuştur. Keşmir'deki putlar bu güzelliğin şimşeğini görürlerse mum gibi eriyeceklerdir. 


\section{Eski Edebiyatta Adı Geçen Ünlü Ressam, Heykeltıraş ve Tarihi Kişilikler}

\section{A. Tasvir Edenler}

1. Mânî: Meşhur Çinli bir nakkaş ve ressamın adıdır. Sasanîler zamanında, Şapur devrinde İran'a gelmiştir. Burada Zerdüștlük ile Hıristiyanlığı incelemiş ve bunların ikisini birleştirerek yeni bir mezhep kurmuştur. Buna Mânî dini (Maniheizm) denilir. Mânî dini en çok Çin'de yayılmış olup kutsal saydıkları kitapları resimlerle süslü imiş. Yaptığı resimler çok güzel olduğu için bu özelliğini müridlerine gökten inen bir mucize olarak göstermiştir. Şapur'un hekimi iken kızını iyileştiremediği için bir aralık İran'a sürülmüş ve Hürmüz'ün oğlu Behram koyu bir Zerdüşt olduğu için onu, derisini yüzdürerek öldürtmüştür. Nigaristan, Erteng veya Erjeng adlı resim mecmuası ile ünlüdür. Edebiyatta daima bu mecmuası ile anılır. Sevgilinin bahsinde çok sözü edilen bir imajdır. Bihzad ile birlikte anıldığı da olur. Sevgilin saçı ve aşığın kendisi Mani'ye benzer (Pala 2004: 297).

Divan şiirinde resim, nakış gibi tasvir sanatlarına değinilen beyitlerde Mânîye çok sık olarak atıfta bulunulur. Bu beyitlerde genellikle Mânînin resimdeki ustalı̆̆ ile bir kıyaslama yapılır. Bunu yaparken bazen Mâniden hiç bahsedilmez ve sadece eserinin adı verilir. Divan şairlerinin bu durumu şiirlerine nasıl yansıttıklarına birlikte göz atalım:

Ger musavvir be-keşed sûret-i o-râ ey dil

Mahv kerdi to derân sûret hayrân-1 Mânî (Kardaş 2012: 269)

(Ey gönül onun yüzünü resm edersen, Mânînin hayranlı̆̆ı seni o resim içinde mahveder.) Şair gönlüne seslenmiş ve eğer onun(sevgili) tasvirini yaparsan, onun güzelliği karşısında Mânî hayrete düşürecek, onun bu hayreti de seni yok eder demiştir. Burada Mânînin hayreti hem sevgilinin güzelliğine, hem de şairin tasvir gücüne olacaktır.

Degil cerîde-i eş'âr sanki cilve eder

Nigârhâne-i Erjeng içinde bikr-i hayâl (Şeyh Galip, K. 29/2:99)

(Erjeng'deki heykel sergisi içinde, sanki orijinal hayaller değil de, eşsiz şiirler tecelli eder.) Erjeng Ünlü Ressam Mânînin resimlerini topladı̆̆ koleksiyonun adıdır. Bu eserdeki heykel resimlerinin güzelliği karşısında şair, bunları sadece orijinal hayaller değil aynı zamanda eşsiz şiirler olarak da görür.

Zülfü nakkâşı suya bir resm eder kim reşk eder Mâni-i Çîn yazdıgı nakş-ı Nigâristân ana (Ahmet Paşa, G. 1/7:95) 
(Nakkaş gibi olan saçları suya öyle bir resm eder ki; Çinli Mânînin Nigaristân'a yazdıkları onu kıskanır.) Sevgilinin saçları nakkaş, yüzü de suya benzetilmiştir. Onun saçları yüzüne düştüğünde öyle bir tablo ortaya çıkar ki, Çinli ünlü ressam Mânînin Nigaristan adlı eserine yaptığı resimler, bu tabloyu kıskanır. Sevgilinin saçı ile Mânî arasında kıyas yapılmıştır.

Bülbülde savt-ı rengîn güllerde sûret-i Çîn

Fasl-ı bahâr Mânî gülşen Nigâr-hâne (Baki, G. 470/3: 392)

(Bülbülde renkli seda, güllerde Çin suretidir; bahar mevsimi Mânî, gül bahçesi, resim atölyesidir.) Bu beyitte ise Mânî bahar mevsiminin getirdiği canlılığı, doğayı süsleyici özeliği ile kıyaslanmıştır.

Açaldan cehre-i hûbun gönül göz yumdu cennetten

Görürken şekl-i rûhânî ne lezzet nakş-ı Mânî'den (Şeyhi, G. 135/2: 231)

(Güzel yüzünü açtı̆ı̆ından beri gönül cennetten gözünü yumdu, ruhanî şekilleri görünce Mânînnin resimlerinde lezzet kalmadı.) Güzel yüzlerin karşısında ne cennet düşüncesinin ne de Mânînin nakşındaki lezzetin ayakta kalamayacağı düşüncesi vardır.

Senüñ nakş itdügüñ elfâz hep rûh-1 musavverdur

Egerçi şekl-i bî-cân yazmada üstâd imiş Mânî (Nev'î, 49 /16: 110)

(Her ne kadar Mânî cansız resimler yazmada üstat imişse de, senin nakş ettiğin sözlerin hepsi düşünülmüş, tasvir edilmiş canlardır.) Şair Mânînin cansız resimler yapmada, kendisinin de canlı tasvirler yapmada üstat olduğunu dile getirmektedir. Burada şairin malzemesi görüldüğü gibi sözcüklerdir.

Hazân yiryüzin eyle itdi münakkaş

Ki Mânî görse anı eyleye gaş (Ahmedî, G. 302/1: 406)

(Sonbahar yeryüzünü öyle nakşetti ki; Mânî onu görse bayılır, kendinden geçer.) Beyitte sonbaharın gelişiyle beraber doğadaki değişimden söz edilmiştir. Burada sonbahar mevsimi nakkaş olarak görülmektedir. Eğer ünlü nakkaş ve ressam Mânî, onun nakışlarını görürse kendinden geçip bayılacaktır.

2. Bihzâd (Behzâd): Büyük bir Türk minyatür ressamıdır. Herat'ta yaşamış, Hüseyin Baykara ve Ali Şir Nevaîden teşvik görmüştür. Eserleri hala müzeleri süslemektedir. Çok taklid edilmiştir. Behzad şeklinde de kullanılır (Pala 2004: 72). Tespit ettiğimiz kadarıyla Divan şiirinde resim ve nakış konusunda 
$132{ }^{*}$ TAED 47

Mânî den sonra en çok atıfta bulunan kişidir. Çoğu zaman Mânî ile beraber aynı beyit içerisinde kendine yer bulmuş ve ona eş tutulmuştur.

Resm-i ebrûsun görüp Mânî n'ola reşk eylese

Bu Nedîmin nakş-ı nevk-i hâme-i Bihzâdıdır (Nedim, G. 22/5: 284)

(Mânî onun kaşlarının resmini görüp kıskansa ne olur, bu Nedim'in, Bihzâd huylu kaleminin nakşıdır.) Şair kendi gücünü ortaya koyarken güzel sanatlardan bir diğeri olan resimle şiiri kıyaslamaya gider. Her ikisi de nakşa dayalıdır ama şairin nakşı sözlerledir. Nakış göze hitap eden bir süs özelliğindedir. Sözün de süslü olanı makbuldür. Bu nakış kelemle işlenir ve bu kalemin işledikleri en ünlü ressamları kıskandıracak kadar güzeldir.

Rengîn ider evsâf-1 ruhuñ hâme-i Bâkî

Ol sûreti virmez sanemâ nakşına Bih-zâd (Baki, G. 35/7: 122)

(Bâkînin kalemi yanağının sıfatlarını renkli tasvir eder; ey put gibi güzel olan sevgili! Senin nakşına Bihzâd o resmi vermez.) Şair sevgiliyi bir puta benzetir ve ona seslenir. Kalemiyle onun yanağının sıfatlarını renkli kıldığını ifade eder. Şair kelimeleri kullanmadaki gücünü göstermek için kelimelerle oluşturduğu bu tasviri Bihzad'ın resimle yapamayacağını iddia eder.

3. Ferhad: Ferhad ile Şirin hikâyesinde aşığı temsil eden Ferhad aynı zamanda mimar ve mühendistir. Divan şiirinde birçok yönüyle ele alınan Ferhad aşağıdaki beyitte ise bir heykeltıraş ve ressam olarak görülmüştür.

Kazardı Kûhken seng üzre dâ'im resm-i Şîrîn'i

Gönül levhine nakl itdüm diyü ol nakş-1 rengîni (Nev'î, G. 505/1: 388)

(Dağ kazıcı Ferhat, o renkli nakşı gönül levhama naklediyorum deyip; Şirin'in resmini daima taşın üstüne kazardı.) Beyitte Ferhad'ın Şirin'e kavuşmak için dağları delmesi olayına atıfta bulunmuştur. Şaire göre Mimar ve mühendis olan Ferhad, dağı kazarken, Şirin'in resmini dağa taşa kazımıştır.

4. Oklidis: İskenderiyeli ünlü matematikçi. İsmi "Öklid" olarak geçer. Geometri alanındaki hüneri ile bütün dünyaya ün salmıştır. Bu ünüyle divan şiirine de konu olmuştur.

Eğer şeklin temâşâ kılsa Oklîdîs okur ahsent Ve ger Bihzâd nakş-1 dil-pezîrin görse der hakkâ (Nedim, Kıt’a 42/22: 174) 
(Oklidis eğer şekline bakıp seyretse aferin, çok iyi derdi; ve eğer Bihzâd, gönle hoş gelen resmini görse, doğru derdi.) Beyitte Öklid ve Bihzad'a atıfta bulunmuştur. Öklid geometride, Bihzad resimde üstat kişilerdir. Sevgili o kadar özenle yaratılmıştır ki, estetik güzelliği karşısında bu iki ünlü kişi, beğenilerini saklayamazlar. Beyitte sevgilinin inceliği ile geometride ince hesapları olan Öklid arasında bağlantı kurulmuştur. Bu durum şiirdeki ince hesapların ve mükemmellik arayışının bir sonucudur.

5. Âzer: Hz. ibrahim'in put yapıp satmakla geçinen ve Kur'an-1 Kerim'de anılan (En'âm/74) babasının adıdır. Bugünkü Azerbaycan kelimesinin onun adına nisbetle kullanıldığı sanılmaktadır. Hz. İsa'nın peygamberliğini ispat için bir mucize olarak dirilttiği kişinin adının da Âzer olduğuna dair bir rivayet vardır. Kelimenin Farsça olarak okunuşu "ateş" anlamı vermektedir. Bu anlamıyla da edebiyatta çok kullanılmış ve kelime oyunlarına sahne olmuştur. Kelimenin bir anlamı da "güzel" demektir (Pala 2004: 49). Yine Nemrud'un putlarını bekleyen kişinin adı da Âzer'dir. Aşağıdaki beyitte de Âzer putlarla beraber kullanılmıştır.

Gamuñdan sûret-i Erjeng bi-hûş

Firâkuñdan büt-i Âzer şikeste (Baki, G. 473/4: 394)

(Senin gamından Erjeng'de yer alan resimler şaşkın ve sersem, senin ayrılığından Azer'in putları kırılmıştır.) Beyitte Mânînin ünlü eseri Erjeng ile Âzer'e atıfta bulunulmuştur.

6. Mimar Sinnimar (Sinimmâr): Numan ibn Münzîr tarafından yaptırılan eşsiz güzellikteki Havernâk sarayını yapan mimârın adı. Bir eşini daha yapmasın diye yaptığı sarayın damından atılarak öldürülmüştür. Böylece mükâfât yerine cezâ görmüştür. Bu nedenle mükâfât yerine verilen cezâya "cezâ-yı Sinimmâr" denilir (Pala 2004: 406). Sinimmâr, Behiştîye ait olan Heft Peyker adlı mesnevide ise Sasanî hükümdarlarından Behrâm-ı Gûr'un yedi iklim padişahlarının kızları ile birlikte olduğu yedi kubbeli köşkü yapan mimar olarak karşımıza çıkmaktadır (Demirel 1995). "Behrâm, Mimar Sinnimar'a yedi kubbeli köşs yaptırır. Bu yedi köşkün her biri değişik renktedir. Behrâm'ın daha önceleri savaştığı ve yendiği yedi iklim padişahları, Behrâm'a olan bağlılıklarını ifade etmek amacıyla kızlarını yollarlar. Behrâm da perşembe gününden başlayarak her gece kızlardan biriyle birlikte olur. Değiş̧ik renkte elbiseler giyen (bulundukları köşke uygun olarak) bu kızlar, hem Behrâm'la birlikte olurlar, hem de babalarının Behrâm'a iletilmek üzere anlattıkları ögütleri içeren kısa hikâyeleri anlatırlar"(Demirel 200ı: 188). Bu yönleriyle Divan şiirine konu olan Sinimmâr, nakşetme ve tasvir etme konusunda üstat olarak görülmüştür. Behiştîye ait olan Heft Peyker mesnevisinden alınan şu beyitlerde Sinimmâr'ın hünerlerinden söz edilmiştir. 
Nakş-perdâz idi pür-kâr hemân

iki barmagıyidi itse nişân

Ne kadar var ise envâ'-1 nukûş

Yazuben eyler idi resm u hûş

Sinnimâr ile olup niçe zamân

Hıdmet itmiş idi üstâde cihân (Demirel, B.1147-1149: 73-74)

\section{B. Tasvir Edilenler}

1. Süleyman ve mührü: Davud peygamberin oğlu olan peygamber. On iki yaşındayken babası yerine tahta geçmiştir. Hem padişah hem peygamberdir... Divan edebiyatında Süleyman peygamber, yukarıda anlatılan kıssalar çevresinde yoğunlaşan düşünceler içinde ele alınır. Özellikle yüzük, karınca, Hüdhüd ve Belkıs ile birlikte çok anılır. Sevgilinin ağzı mühre benzetildiği zaman Süleyman'dan bahsedilir. Şair sevgilisine Süleymanlık yakıştırdığı zaman onun ihtişamından bahsetmektedir. Karınca aczin; Süleyman ise iktidar ve gücün timsali olarak tezat içinde verilir. Şair övdügü kişiye Süleyman dediği zaman kendisini karınca kadar aciz gösterir (Pala 2004: 411).

Divan şiirine birçok yönüyle konu olan Süleyman peygambere, aşağıdaki beyitte mührü ile beraber nakış konusunda değinilmiştir.

Sun' nakkâşı ne nakş itti hat-ı la'lüñde kim

Yazdı bir kem zerreye mühr-i Süleymânı dürüst (Nev'î, G. 25/2: 188)

(Allah senin kırmızı dudağına ne nakşetti ki; Süleyman'ın mührünü biraz daha az doğru yazdı?) Beyit Allah'ın yaratıcı sıfatı üzerine kurulmuştur. Allah sevgilinin kırmızı dudağını öyle bir nakşetmiş ki şair bunun yanında Süleyman'ın mührünün bile değersiz kalacağını iddia ederek mübalağa sanatına başvurmuştur. Bilindiği gibi Süleyman peygamberin mühründe, Allah'ın en büyük ismi olan “ism-i Azam" yazılıdır. Beyitte bu duruma da atıfta bulunulmuştur.

2. Yusuf: Divan şiirinde adı en çok anılan peygamberlerden biri de Yusuftur. Harikulade güzelliği ile çok zaman sevgili ona benzetilir. Hatta sevgili, Yusuf-ı sanî (ikinci Yusuf) olarak nitelenir. Ay ile güneşin ona secde etmeleri, kuyuya atılması, terazi ile tartılıp ağırlı̆ınca altın karşı̆ı̆̆ satılması, Züleyha ile olan maceraları, zindana atılması, güzel rüya tabir etmesi, Yakub'dan ayrı oluşu, köle iken Mısır'a sultan oluşu vs. kıssalar nedeniyle birçok beytin konusunu oluşturur. Bunun en büyük amili hiç şüphesiz Yusuf u Zeliha mesnevileridir. Mah-1 Kenan diye nitelenen odur. Lakabı ise Sinan'dır (Pala 2004: 484). 
Tırâş itdi göñülden gayr resmin tîg-i bürrânı

Vücûdum degerinüñ Nev'iyâ 'unvânıdur Yûsuf (Nev'î, G. 215/5: 267)

(Ey Nevi! Keskin kılıç gönülden diğer resimleri tıraş etti; Yusuf vücudumun değerinin ünvanıdır.) Beytin ilk mısrasında resim ve heykel ile ilgili terimlere yer verilmiştir. Tıraş etmek heykele ait terimlerdendir. ikinci mısrada ise $\mathrm{Yu}$ suf peygambere atıfta bulunmuştur. Şair kendini Yusuf kadar değerli bulur.

3. Mecnun: Kelime anlamı deli olan Mecnun daha çok Leyla ve Mecnun mesnevisinin kahramanı olarak bilinir. Divan şairlerinin en çok işlediği mazmunlardandır. Aşağıdaki beyitlerde de tasvir konusuyla bağlantılı olarak işlenmiştir.

Peyker-i zerd ü nizârum var iken 'âkil midür

Hey'et-i Mecnûn yazan sûretger-i dîvâne nakş (Baki, G. 213/5: 231)

(Sararmış yanağım ve zayıflı̆̆ım var iken, divane ressamın Mecnun'un halini nakşetmesi akıl işi midir?) Beyitte Mecnunun vasfı olan delilik ressama yüklenmiştir. Şairin sararmış yüzü ve zayıflı̆ı varken ressamın Mecnun'u resmetmesi şaire göre deliliktir.

'Aceb mi ger yaza nakkâş nakş-ı Mecnûn'ı

Cihânda yazım bir 'âşık idi dîvâne (Nev'î, G. 433/4: 358)

(Eğer nakkaş cihanda deli bir aşık olan Mecnun'un nakşını yazarsa şaşılır mı?) Bu beyitte ise bir önceki beyitin aksine Mecnun'un divane bir aşık olduğu, bu yüzden nakkaşın onu resmetmesine şaşılmaması gerektiği söylenmiştir.

\section{Sevgilinin Güzelliği ve Putla Kıyaslanması}

Gelse bu sûretle bütgede-i hüsne eger

Bütler îmân getirip der sanemâ hôş geldin (Şeyh Galip, G.189/5: 355)

(Eğer bu suretle güzel puthaneye gelirse, putlar iman getirip, "ey put! Hoş geldin" der.) Divan şiirinde sevgili güzelliği nedeniyle puta benzetilir. Sevgili, put kadar güzel ve acımasız olduğu için bu şekilde hitap edilir. Bu beyitte "sanem" sözcüğüyle bu durum gerçekleştirilmiştir. Şaire göre sevgili bu güzelliğiyle puthaneye gitse oradaki putlar onun önünde eğilecek ve iman getirecektir.

Billâh ey büt-hâne-i hüsnün büt-i 'ayyâresi

Nice mermerden düzülmüşdür yüregin hâresi (Ahmet Paşa, G. 349/ı: 256)

(Allah için, ey güzel puthanenin dolandırıcı, hilekâr putu! Taş yüreğin nice mermerden düzülmüştür.) Bu beyitte de sevgili güzelliği nedeniyle puta, yüreği 
de heykele benzetilmiştir. Şair sevgiliyi taş kalpli bir heykel olarak tasvir etmiştir. "hare-mermer-büt-büthane" sözcükleriyle tenasüp yapılmıştır.

Ol büt-i tersâ sana mey nûş eder misin demiş

El-aman ey dil ne müşkilter su'âl olmuş sana (Nedim, G. 2/5: 273)

(Ey gönül! O Hıristiyan güzeli sana şarap içer misin demiş; eyvah! Sana ne zor bir soru sorulmuş.) Şair kendi gönlüne seslenmiştir. Beyitte meyhane tasviri yapılmıştır. Put gibi güzel olan Hıristiyan güzeli, şairin gönlüne şarap içer misin diye sormuş. Şair şarabın etkisiyle bu sorunun zorluğunu dile getirmiştir.

Sûret-i zîbâya meyl itsem baña ta'n eyleme

Var su'âl it böyle dil-keş nakş iden nakkâşına (Baki, G. 421/3: 361)

(Süslü resme meyil edersem beni ayıplama; var böyle gönül çeken nakış eden nakkaşa sor.) Beyitte tasviri ayıplayanlara bir tepki vardır. Şair tasvire meylettiği için onu kınayanlara gidin, gönül çekici nakış yapan nakkaşa sorun demektedir.

Sanemâ gün yüzün âyine-i cândır bilirim

Dü cihân nakşı kamu anda 'ayândır bilirim (Şeyhi, G. 119/ı: 215)

(Ey put gibi güzel olan sevgili! Gün yüzün can aynasıdır, bilirim; iki cihanın nakşının hepsi onda aşikârdır bilirim.) Sevgili güzelliği nedeniyle puta, yüzü de parlaklığı nedeniyle gün yüzüne, güneşe benzetilmiştir. Bu güzellik ilahi güzelliğin aksidir. $\mathrm{O}$ yüzden o güzel yüzde her iki dünyanın nakışları aşikârdır.

Kurı sûret midür ey pîr-i mugân büt-hâne

Yohsa sol bir saneme 'âşıłk-1 dîdâr mısın (Nev'î, G. 357/2: 326)

(Ey başrahip! Puthane kuru suret midir? Yoksa şöyle bir saneme aşık mısın?) Şair başrahibe seslenmektedir. Puthane kuru suretlerden mi oluşur diyen şair, puta benzettiği güzeli gösterip şöyle bir güzele mi aşıksın diye de ekler. Yine sevgili güzelliği nedeniyle puta benzetilmiştir.

\section{Sevgilinin Kaşı}

Bütân kim secde-i ebrû-yı matlûb eylemişlerdir

Bizi hem deyre hem mihrâba mensûb eylemişlerdir (Ş. Galip, G. 46/i: 274)

(Talep edilen kaşlara secde eden putlar, bizi hem kiliseye hem mihraba mensup eylemişlerdir.) Sevgilinin güzellik unsurlarından birisi de kaşlarıdır. Şekli 
itibariyle birçok şeyle ilgi kurulur. Kaş bazen mihrap, bazen kıble ve secde yeridir. Âşık kaşlara yönelerek cemale ulaşmaya çalışır. Beyitte leff ü neşr sanatından yola çıkılarak güzel bir hayal ortaya konulmuştur.

Ol büt-i Çîn ü Hıtâ kim turra-i müşgîni var

Ne hatâmız gördü kim ebrûlarının çîni var (Ahmet Paşa, G. 52/l: 120)

(O misk kokulu saçları olan Çin ve Hıtâ putu, ne hatamızı gördü ki kaşlarını çatıyor.) Beyitte kaşlarını çatan bir güzelin tasviri yapılmıştır. Bu misk kokulu saçları olan put gibi güzelin kaş çatması ya öfke ya da sitem içindir.

Resm-i ebrûsun görüp Mânî n'ola reşk eylese

Bu Nedîmin nakş-ı nevk-i hâme-i Bihzâdıdır (Nedim, G. 22/5: 284)

(Mânî onun kaşlarının resmini görüp kıskansa ne olur, bu Nedim'in, Bihzâd tabiatlı kaleminden çıkan nakşıdır.) Şair sözcüklerle şiirinde sevgilinin kaşlarının tasvirini yapmıştır. Şaire göre bunu Mâni görse kıskanabilir çünkü, yaptığı tasvir Bihzad tarzına uygundur.

Gözine kaşına meşgul olma hûbuñ Nev'iyâ

Vir göñül ol resmi şîîn gösteren nakkâş̧ın (Nev'î, G. 458/5: 369)

(Ey Nev'i o güzelin gözüyle kaşıyla meşgul olma, o tatlı resim gösteren nakkaşına gönül ver.) Şair güzelin kaşı gözüyle meşgul olunmaması gerektiğini, onu böyle yaratan nakkaşa gönül vermek gerektiğini savunur. Bu nakkaş cemal vasfi taşıyan Allah'tır.

\section{Sevgilinin Boyu ve Yürüyüşü}

Şol serv ki dîvârına nakş eyledi nakkâş

Teşbîh olunmaga yarardı ona Tûbâ (Ahmet Paşa, K. 11/28: 21)

(Nakkaşın duvarına nakşettiği şu servi, Tuba ağacı ona benzetilmeye yarardı.) Tuba ağacı cennette olduğuna inanılan ağacın adıdır. Divan şiirinde Tuba ağacı gölgesi ve boyu nedeniyle anılır. Sevgilinin boyu Tuba'ya benzetilir. Yukarıdaki beyitte servi sevgili yerine kullanılarak teşhis yapılmıştır. Sevgili nakkaş tarafından duvara nakşedilmiş ve bir tablo meydana getirmiştir.

Şîve-i reftâr-ı kaddüñ yazmada ditrer eli

Gerçi Mânî nakş ider serv-i gülistânı dürüst (Nev'î, G. 25/3: 188)

(Mânî, Her ne kadar gül bahçesindeki serviyi düzgün nakş etse de; senin boyunun yürüyüşündeki edayı yazarken eli titrer.) Divan şiirinde sevgilinin boyu 
serviye teşbih edilir. Burada da şair bu iki mazmunu mukayese ederek, Mânînnin serviyi düzgün çizdiğini ancak sevgilinin boyuna gelince ellerinin titrediğini ifade eder. Çünkü nazlı nazlı salınmada sevgili serviyi de geçmiştir.

\section{Sevgilinin Dudağı}

Leb-i cânân-bahşına serdâde-i imân-ı Îsî

Kâkülü bütgede-i perçeminin kıssîsi (Şeyh Galip, G.334/1: 430)

(Sevgilinin can bağışlayan dudağına, baş vermiş olan İsa'nın imanıdır, Saçlarının puthanesinde kaküller papazdır.) Divan şiirinde sevgilinin güzellik unsurlarından biri de dudağıdır. Aşığa can bağışlayan her türlü ilaç onda mevcuttur. Söyledikleriyle ìsa nefeslidir. Yukarıdaki beyitte de sevgili bu özellikleriyle ìsa'ya benzetilmiştir. İkinci mısrada ise sevgilinin saçları puthane olarak düşünülmüş ve kaküller de Keşiş olarak kullanılmıştır.

Erseydi Çîn diyârına lâ'lin cevâhiri

Hergiz komazdı leb yerine büt-nigâr lâ'l (Ahmet Paşa, K. 12/41: 29)

(Dudağının cevheri Çin diyarına erseydi, putçu asla dudak yerine kırmızı süs taşları koymazdı.) Sevgilinin dudağı kırmızılığı nedeniyle yakuta benzetilmiştir. "büt-nigar" hem put yapan hem de portreci anlamına gelecek şekilde kullanılmıştır. Şaire göre eğer Çin'de sevgilinin dudağı görülmüş olsaydı ne putçular ne de ressamlar yakut taşını eserlerinde kullanmazlardı.

\section{Sevgilinin Saçı}

Bilmem âteş-hânemi tasvîr eylersin hemân

Çîn-i zülfünde ana kurbet-nigâr oldukça ben (Şeyh Galip, G. 241/4: 385)

(Saçlarının kıvrımında ona ben yakın olarak resm oldukça, Mecusi ibadet yerini öylece tasvir eylersin bilmem.) Divan şiirinde sevgiliye ait unsurlardan en çok kullanılanı saçtır. Birçok yönüyle ele alınan sevgilinin saçı, sayısız benzetmeye konu olur. Renk yönünden küfr, kâfir ve putperest olarak düşünülür. Bu beyitte de yanaktaki ben ile birlikte kullanılmış ve ortaya çıkan tablo Mecusi ibadet yeri olarak düşünülmüştür.

Zülfü sol nakkâş̧ır kim suya nakş-ı Çin yazıb

Mânîyi mât eyledi bir berg-i müşg-âgin salıb (Ahmet Paşa, G. 12/5: 101)

(Sevgilinin saçları öyle bir Nakkaş'tır ki; suya Çin resimleri yazıp, misk ile dolu bir yaprağı salarak Mânî́yi mat eyledi.) Bu beyitte de sevgilinin saçı nakkaş, 
yüzü suya benzetilmiştir. Onun saçı yüze düşünce Çin resimleri ortaya çıkmaktadır. Sevgilin saçları nakkaşlıkta o kadar iddialıdır ki Mânı̃yi bile mat eder. Ayrıca beyitte sevgilinin saçına ait olan nakkaşlık ve misk kokulu olma özellikleri bir arada verilmiştir.

Âb-rûyuñdan irer âyîne-i hûrşîde tâb

Tâb-ı zülfüñden düşer levh-i zamîr-i kâne nakşs (Baki, G. 213/3: 231)

(Yüzünün suyundan güneşin aynasına ışık ulaşır, Saçının kıvrımından düşer gönüldeki levhaya nakış olur.) Beyitte sevgilinin portresi çizilmiştir. Sevgilinin yüzü üstüne düşen saçlar levhaya çizilen nakış ve resim olarak düşünülmüştür.

Saçın küfrün yüzü nûrun görürse zâhid ü râhib

Bu mescidden diye yâ hû vü ol büt-hâneden ya hû (Şeyhi, G. 145/5: 241)

(Zahid ve rahip, saçının karalığını ve yüzünün nurunu görseler, biri mescitten "yâ hû (Ey Allahım" digeri de kiliseden "yâ hû" diye söyler.) Beyitte "Zahid-mescid", "rahip-büt-hâne" arasında leff ü nesr sanatı vardır. Küfr ile nûr arasında ise tezat bulunmaktadır. Küfr kelimesi tevriyelidir. Beyitte sevgilinin yüzü mescid, saçları ise kilise yerine kullanılmıştır.

\section{Sevgilinin Gözü}

Gözine kaşına meşgul olma hûbuñ Nev'iyâ

Vir gönül ol resmi şîîn gösteren nakkâşına (Nev'î, G. 458/5: 369)

(Ey Nev'i o güzelin gözüne kaşına zaman ayırma, o tatlı resim gösteren nakkaşına gönül ver.) Şair güzelin kaşı gözüyle meşgul olunmaması gerektiğini, onu böyle yaratan nakkaşa gönül vermek gerektiğini savunur. Bu nakkaş cemal vasfi taşıyan Allah'tır.

\section{Sevgilinin Yanağı ve Yüzü}

Çîn nigâristânını nakş-ı ruhundur mât eden

Sana nisbet mâh-rûlar sûret-i Erjengidir (Ahmet Paşa, G. 77/5: 131)

(Çin'in put ve resimlerle dolu sergisini mat eden senin yanağının resmidir; seninle kıyaslanabilecek ay yüzlüler Erjeng' in resimleridir.) Beyitte "nakş" resim, hile ve renk anlamlarına gelecek şekilde kullanılmıştır. Böylece sevgilinin yanağı hileyle Çin'deki put ve resimleri mat etmiştir. Yanağın güzelliğine ancak Mânînin eseri Erjeng'de bulunan ay yüzlülerin resimleri karşı koyabilir. 
Bulmaya ol hadd-i gül-gûn üzre hattuñ hâletin

Müşg-i terden yazsalar berg-i gül-i handâne nakş (Baki, G. 213: 230)

(Açılmış gülün yaprağına taze miskten nakış yazsalar; o gül renkli yanağının üzerinde yeni çıkan tüylerin suretini bulamazlar.) Beyitte sevgilinin yanağı rengi itibariyle güle teşbih edilmiş ve yüzünde yeni çıkan tüyler de nakış olarak düşünülmüştür. Şaire göre gül yaprağında bile bu nakıştaki estetik yoktur.

Açaldan cehre-i hûbun gönül göz yumdu cennetten

Görürken şekl-i rûhânî ne lezzet nakş-ı Mânî'den (Şeyhi, G. 135/2: 231)

(Güzel yüzünü açtı̆̆ından beri gönül cennetten gözünü yumdu, ruhanî şekilleri görünce Mânînin resimlerinde lezzet kalmadı.) Sevgilinin güzel yüzü şaire cenneti bile unutturmuştur. Onun yanağının ruhani şeklini gördükten sonra Mânînnin resimlerinde de lezzet kalmamıştır.

Sâde-rûdur demiş erbâb-ı nazar ol şûha

Biz o gül-çehreyi zîverle münakkaş biliriz (E. Zihni, G.147/4: 184)

(Bakanlar o cilveli güzele temiz yüzlü, tüysüzdür demiş; biz o gül çehreyi süs ile nakşedilmiş biliriz.) Sevgiliye bakanlar onun yüzünü sade görürken, şair onun yüzündeki ince tüylerin süslü bir nakış oluşturduğunu ve aşık olmadan bakanların bunu göremeyeceğini iddia eder.

Kalem kıla ısırup barmagını

Görürse yüzüñüñ nakşını Mânî (Ahmedî, G. 721/3: 614)

(Mânî senin yüzünün nakşını görürse, parmağını kalemi yapıp ısırır.) Sevgilinin yüzündeki ayva tüyleri bir nakış gibi durur. Ünlü ressam Mâni bu nakşı görürse kalem sanıp parmağını ısırır.

\section{Sevgilinin Gamzesi (Yan bakışı) ve Kirpikleri}

Sûzen-i müjgânı geçdükçe dil-i pür-dâgdan

Şanuram işler harîr üzre karanfül nakşını (Nev'î, G. 465/4: 37ı)

(Kirpiklerin iğnesi yara ile dolu gönülden geçtikçe, karanfilin nakşını ipek üzerine işler sanırım.) Divan şiirinde sevgilinin bakışı gamzeyi meydana getirir. Bu bakış üzerine sayısız anlam vardır. Gamze en çok ok ve kılıcı andırır ve hedefi aşığın gönlüdür. Şair gamzeden çıkan okların yaralı gönülden geçmesini, ipek mendil üzerine karanfil nakşetmeye benzetir. 


\section{Sevgilinin Beni}

Hâl-i ruhun ki kesmedi zülfün alâkasın

Ol kâfirin ta'alluku bu büt-perestedir (Ahmet Paşa, G. 41/4: 115)

(Yanağındaki benin saçınla ilişkisini kesmedi, o kâfirin ilgisi bu puta tapanadır.) Divan şiirinde yüzde bulunan benler ve bu benlerin siyahlığından çok sık olarak bahsedilir. Beyitte sevgilinin yanağındaki beni ve saçları siyah oluşları neticesinde kâfir ve putperest olarak düşünülmüştür. Yanaktaki ben putperest ve saçlar da kâfir yerine kullanılmıştır.

Bilmem âteş-hânemi tasvîr eylersin hemân

Çîn-i zülfünde ana kurbet-nigâr oldukça ben (Şeyh Galip, G. 241/4: 385)

(Saçlarının kıvrımında ona ben yakın resm oldukça, neden öylece ateşgedemi tasvir eylersin bilmem.) Bu beyitte de sevgilinin saçı ve beninin oluşturduğu tablodan bahsedilmiştir. Her ikisi de renk olarak siyahtır. Böyle olunca ikisi de küfre yakındır. Saç kâfir ben ise putperesttir. Beyitte geçen "âteş-hâne" sözcügüu de Mecusi tapınağı, ateşgede anlamındadır. Beyitte "ben" sözcüğü, vücutta çıkan siyah nokta ve birinci tekil şahıs zamiri anlamlarına gelecek şekilde kullanılarak tevriye yapılmıştır.

\section{3. Şairin ve Aşı̆̆ın Vasıfları ile ilgili Olanlar}

Divan şiirinde şairler kendisinden ve âşıktan bahsedince resim, nakış ve heykel ile ilgili terimlere başvururlar. Buna örnek teşkil eden aşağıdaki beyitlere birlikte göz atalım:

Peyker-i zerd ü nizârum var iken 'âkil midür

Hey'et-i Mecnûn yazan sûretger-i dîvâne nakşs (Baki, G.213: 231)

(Sararmış yanağım ve zayıflı̆ı̆m var iken, divane ressamın Mecnun'un halini nakşetmesi akıl işi midir?) Şair kendisini Mecnunla karşılaştırmış ve sararmış yüzü ile zayıflı̆̆ varken ressamın Mecnun'u resmetmesini delilik olarak nitelendirmektedir.

Ben sâde-dile reng ile nakş oynadı bir bul

Bu nakş-1 nigâra gözüm andan nigerândır (Şeyhi, G. 34/7: 130)

(iş̧lenmiş bir tahta ben saf gönüllüye hile ile oyun oynadı; gözüm bu nakış ve resme o yüzden bakar.) Şair kendini saf gönüllü olarak nitelemektedir. Beyitte "reng ve nakş" sözcükleri tevriyeli kullanılmıştır. "nakş oynamak" deyimi ise 
"oyun etmek, hile yapmak" anlamında kullanılmıştır. "nigar" sözcüğü de "nakş" ile tenasüp olarak kullanılmış ve mecaz-1 mürsel yoluyla da sevgili yerine kullanılmıştır. Şair resim gibi güzel olan sevgiliye bakış nedeni olarak, sevgilinin ona oyun oynamasını göstermiştir.

Resm-i cefâ vü cevri dilüñden tırâş kıl

Bir sikke kaz efendi bugün mermer üstine (Nev'î, G. 426/4: 355)

(Efendi! Cefa ve eziyetin resmini gönlünden tıraş et; bugün mermer üstüne bir sikke kaz.) Beyitte resim ve heykele ait terimler bir arada kullanılmıştır. Şairin gönlü eziyet ve gamla dolu olduğundan yaralı olarak nitelendirilir. Bu yaralar şaire resim gibi gelmiştir. Şair bu resimleri gönlünden tıraş ederek mermere kazımak ister.

Kâşâne-i murâdım pür-zîver eyledim

Nakş u Nigâr-1 dîde-i hûnbâr-1 ye'sden (Şeyh Galip, G. 259/3: 393)

(Muradımın köşkünü, kederden kanlı yaş döken gözümün nakşı ve resmi ile süsledim.) Şair muradını köşk olarak nitelendirmektedir. Bu köşkü de kanlı gözyaşlarından oluşan resim ve nakışlarla süslemektedir.

\section{IV. Çeşitli İnanış ve Uygulamalar}

Divan şiirinde resim ve heykel konusu işlenirken ilgi kurulan başka bir konu da çeşitli inanış ve uygulamalar konusudur. Bu konuda tespit ettiğimiz unsurların başında muska ve hamail gibi inanışlar gelir. Özellikle nazardan korunmak için boyna takılan muskalar şiirde çok geçer. Bu durumda aşığın kolu muska yerine geçer.

Ger yavuz göz degmesin dersen salın ey serv-i nâz

Boynuna Ahmed kolundan heykel-i zerrîn salıb (Ahmet Paşa, G. 12/9: 101)

(Ey dalları yana sarkan servi (uzun boylu sevgili)! Eğer kötü göz değmesin dersen; boynuna Ahmed'in kolundan altın heykel takıp salın.) Sevgili uzun boyu itibariyle serviye benzetilmiştir. Boyu o kadar uzundur ki şair nazar değmesinden korkmaktadır. Şair buna engel olmak için sevgiliye kendi kolunu hamail (muska) olarak takmasını teklif eder. Böylece şair kollarını sevgilinin boynuna dolandıracaktır. Asıl maksadı budur. Şair kendi kolunu altın heykel olarak nitelendirir. 
Hamâyil gibi boynuna kolun kıl Ahmed'in heykel

Ki saklaya seni Bâri yavuz gözden yavuz dilden (A. Paşa, G. 231/9: 202)

(Ahmed'in kolunu heykel kıl muska gibi boynuna tak, Yaratan seni kötü gözden, kötü gönülden saklasın.) Şair bu beyitte de, sevgiliye kötü göz ve gönüllerden sakınmak için kendi kolunu muska gibi boynuna asmasını teklif eder. Böylece hem sevgili kötü göz ve gönüllerden korunacak hem de şair kolunu sevgilinin boynuna dolanacaktır.

Levhinde sînesinin yüz da'vet okuyaydım

Heykel yerine bir kez kılsa kolun hamâyil (Şeyhi, G.110/2: 206)

(Heykel yerine bir kez kolunu muska kılsa, Sinesinin levhasında yüz davet okurdum.) Bu beyitte de aşı̆̆ın kolunun muska olarak heykel yerine boyna asılması düşüncesi vardır

\section{V. Şiirini ve Kendini Övme Vasıtası Olarak Kullanma}

Divan şairleri kendilerini ve şiirlerini övmek için resim ve heykelden yararlanmışlardır. Gerek ünlü ressamlarla kendilerini kıyaslayarak, gerekse de şiir ve resmi kıyaslayarak şairler şiire ne kadar hâkim olduklarını gösterme çabasına girmişlerdir. Şairler, şiirlerinde canlı tasvirler yaratmadaki hünerlerini ifade etmek için tasvire ait unsurlardan yararlanmışlardır.

Resm-i ebrûsun görüp Mânî n'ola reşk eylese

Bu Nedîmin nakş-ı nevk-i hâme-i Bihzâdıdır (Nedim, G. 23/5: 284)

(Mânî onun kaşlarının resmini görüp kıskansa ne olur, bu Nedim'in Bihzâd tabiatlı kaleminden çıkan nakşıdır.) Şair kendi gücünü ortaya koyarken güzel sanatlardan bir diğeri olan resimle şiiri kıyaslamaya gider. Her ikisi de nakşa dayalıdır ama şairin nakşı sözlerledir. Nakış göze hitap eden bir süs özelliğindedir. Sözün de süslü olanı makbuldür. Bu nakış kalemle işlenir ve bu kalemin işledikleri en ünlü ressamları kıskandıracak kadar güzeldir.

Kimse Ahmed gibi nakş etmez kitâbın hüsnünün

Ne kadar nakkâş̧ olursa edemez Mânîyle bahs (Ahmet Paşa, G. 22/8: 106)

(Kimse Ahmed gibi güzel kitap nakş edemez, ne kadar nakkâş olursa olsun kimse Mânî ile bahse giremez.) Şair şiir alanında en iyisi olduğunu iddia etmiştir. Bu iddiasını kuvvetlendirmek için, kendini resim alanında büyük üne sahip olan Mânî ile karşılaştırmıştır. 
Rengîn ider evsâf-1 ruhuñ hâme-i Bâkî

Ol sûreti virmez sanemâ nakşına Bih-zâd (Baki, G.35/7: 122)

(Bâkĩnin kalemi yanağının sıfatlarını renkli eder, ey put gibi güzel olan sevgili! Senin nakşına Bihzâd o resmi vermez.) Şair sevgiliyi bir puta benzetir ve ona seslenir. Kalemiyle onun yanağının sıfatlarını renkli kıldığını ifade eder. Şair kelimeleri kullanmadaki gücünü göstermek için kelimelerle oluşturduğu bu tasviri ünlü ressam Bihzad'ın resimle yapamayacağını iddia eder.

Te'sîr alınır heykel-i eş'âr-ı terimden

Zihnî gibi bir nâdire-sencân-ı cihânız (Erzurumlu Zihni, G. 139/5: 180)

(Taze şiirlerimin heykelinden tesir alınır; Zihnî gibi cihanın nükteli söz söyleyen zarif bir kimseyiz.) Şair üslup açısından taze olarak nitelendirdiği şiirini heykele teşbih etmiştir.

Senüñ nakş itdügüñ elfâz hep rûh-1 musavverdûr

Egerçi şekl-i bî-cân yazmada üstâd imiş Mânî (Nev'î, 49/16: 110)

(Her ne kadar Mânî cansız resimler yazmada üstat imişse de, senin nakş̧ ettiğin sözlerin canlı tasvirlerdir.) Şair şiirde dili kullanmadaki hünerini ortaya koymak için kendini Mânî ile kıyaslamıştır. Şaire göre Mânî cansız resimler yapmada, kendisi de şiirde canlı tasvir yapmada üstattır.

Bu resme ki Ahmedî yazar yüzüñ vasfını dîvâne

Gerek nakş ögrene Mânî bu dîvân-ıla defterden (Ahmedî, G. 486/6: 498)

(Ahmedî senin yüzünün vasfını bu resimle divân'ınına yazar, Mânî bu defter ile divândan nakşı öğrenmelidir.) Şair, divanına sevgilinin yüzünün nakşını işlediğini ve Mânî́nin bu divandan nakşı öğrenmesi gerektiğini ileri sürmüştür.

Bâlâ-rev olan ancak ma'nâ-yı mücerreddir

Tasvîri Mesîhânın büt-hânede kalmıştır (Şeyh Galip, G. 59/2: 282)

(Yüksekte giden ancak soyut manadır, Hz. İsanın tasviri puthanede kalmıştır.) Resim ve şiir karşılaştırılmıştır. Şair, tasvir yapmanın kilise ve puthanelerde kaldığını, şiirde önemli olanın mana olduğunu ifade etmiştir.

Görüldüğü gibi, divan şairleri resim ve heykel sanatları ile ilgili terminolojiyi şiirlerinde belli durumlar çerçevesinde işlemişlerdir. Divan şairinin son büyük 
temsilcilerinden olan Yahya Kemal Beyatlı da "Bergama Heykeltraşları" adlı şiirinde bu terminolojiden yararlanmıştır (Beyatlı 1990: 150).

\section{Sonuç}

Genel olarak, Sanat insanın güzellik karşısında duyduğu heyecan ve hayranlı̆̆ı uyandırmak için ortaya koyduğu yaratıcılık olarak tanımlanır. Sanat kendi arasında dallara ayrılır. Bu dalların başında görsel sanatlar gelir. Görsel sanatlar içerisinde en dikkat çekici olanları Resim ve Heykeldir. Edebiyat ise güzel sanatlar arasında kabul edilmektedir. Edebiyat diğer sanat dallarında olduğu gibi Resim ve Heykel sanatlarından da yararlanır. Edebiyatın malzemesi kelimelerdir. Dolayısıla bu sanatları kullanırken dilin olanaklarından yararlanır. Divan şiiri de görsel sanatlara bu açıdan yaklaşır. Divan şiiri kelimelerin gücünden ve belirli mazmunlardan yararlanarak Resim ve Heykel sanatlarını şiire taşımıştır. Şüphesiz bunda İslam'da var olan tasvir yasağı varsayımının büyük etkisi olmuştur. Şairler başka din ve kültürlerin etkisiyle resim ve heykel gibi sanatların terminolojilerinden yararlanmış ve bu terminolojiyi şiirde kullanmışlardır. Bu terminolojiye bütün divan şairlerinin şiirlerinde rastlamak mümkündür. Öyle ki divan şiirinin son başarılı temsilcilerinden olan Yahya Kemal Beyatlı da "Bergama Heykeltraşları" adlı şiirinde bu terminolojiden yararlanmıştır.

\section{KAYNAKÇA}

AKDOĞAN, Yaşar (Haz.). Ahmedi, Divan. Ankara: Kültür ve Turizm Bakanlı̆̆ Yayınları, 1988.

AYVAZOĞLU, Beşir. Așk Estetiği. İstanbul: Ötüken Neşriyat A.Ş., 1993.

BEYATLI, Y. Kemal. Kendi Gök Kubbemiz. Ankara: Kültür Bakanlığı Yayınları, 1990.

BURCHKARDT, Tıtus. İslam Sanatı Dil ve Anlam (Terc. Turan Koç). İstanbul: Klasik Yayınları, 2005.

ÇAM, Nusret. İslam'da Sanat Sanatta íslam. Ankara: Akçă̆ Yayınları, 2008.

ÇETiŞLi, ìsmail. Edebiyat Sanatı ve Bilimi. Ankara: Akçă̆ Yayınları, 2008.

DEMiREL, Şener. Behiştî ve Heft Peyker (Metin-Inceleme). Yüksek Lisans Tezi. Fırat Üniversitesi Sosyal Bilimler Enstitüsü. Elazı̆̆. 1995.

"16. Yüzyıl Divan Şairlerinden Behiştî ve Heft-Peyker Mesnevisinin Tematik Açıdan incelenmesi”. Selçuk Üniversitesi Türkiyat Araştırmaları Dergisi, Sayı 9 (Bahar/2001): 187-217.

HOLliNGSWORTH, Mary. Dünya Sanat Tarihi (Çev. Banu Ergüder ve Rengin Küçükerdoğan). ìstanbul: İnkılap Kitabevi, 2009.

iSEN, Mustafa ve Cemal KURNAZ (Haz.). Şeyhi, Divan. Ankara: Akçağ Yay., 1990.

iSEN, Mustafa ve diğer. Eski Türk Edebiyatı El Kitabı. Ankara: Grafiker Yay., 2006.

KALKıŞıM, Muhsin (Haz.). Şeyh Gâlîb Divanı. Ankara: Akçă̆ Yayınları, 1994.

KARDAŞ, Sedat. Tâli’̂̂n nin Farsça Divanı ve Necâtî Bey Divanı ile Mazmunlar Açısından Mukayesesi (Inceleme-Edisyon Kritik- Transkripsiyonlu Metin-Tercüme-Mukayese). Yüksek Lisans

Tezi. Atatürk Üniversitesi, Sosyal Bilimler Enstitüsü. Erzurum. 2012

KüÇÜK, Sabahattin (Haz.). Baki, Divan. Ankara: TDK Yay., 1994. 
$146{ }^{*}$ TAED 47 S. KARDAS

MACiT, Muhsin (Haz.). Erzurumlu Zihni, Divan. Ankara: Kültür ve Turizm Bakanlı̆̆ı Yayınları, 2001.

(Haz.). Nedim, Divan. Ankara: Akçăg Yayınları, 1997.

MAHiR, F. Banu (Haz.). Türkiye Diyanet Vakfi İslâm Ansiklopedisi. Cilt 30. İstanbul. 2005.

NASR, Seyyid Hüseyin. İslam Sanatı ve Maneviyatı. İnsan Yayınları. İstanbul 1992. s. 99'dan Yakup Çelik, Sanat ve Edebiyatta Temel Kavramlar. Nehir Yayınları. Istanbul 2002. s.103.

OKÇU, Naci. Şeyh Gâlip (Hayatı, Edebi Kişiliği, Eserleri, Şiirlerinin Umumi Tahlili ve Divanının Tenkitli Metni). Ankara: Kültür Bakanlığı Yayınları. 1993.

ÖZTÜRK Mürsel ve Derya ÖRS (Haz.). Mütercim Asım Efendi, Burhan-ı Katı. Ankara: TDK, 2009.

PALA, İskender. Ansiklopedik Divan Şiiri Sözlügüu. İstanbul: Kapı Yayınları, 2004

SÖZEN, Metin. Geleneksel Türk El Sanatları. İstanbul: Hürriyet Gazetecilik ve Matbaacılık A.Ş., 1998.

TARLAN, Ali Nihat. (Haz.). Ahmet Paşa Divan. Ankara: Akçă̆ Yay.,1992.

, (Haz.). Necati Beg Divanı. Ankara: Akçağ Yay., 1992.

TULUM, Mertol ve M. Ali TANYERi (Haz.). Nev'i Divan (Tenkidli Basım). İstanbul: ìstanbul Ün. Edebiyat Fakültesi Yayınları, 1977.

TÜRKER, Kemal. “ìslamiyet'te Tasvir Sanatı”. Kümbet. sayı: 16 Ocak-Mart 2010, s.30-Mart 2010. 